\title{
ANALISIS REAKSI PASAR ATAS PENGGABUNGAN USAHA PADA PERUSAHAAN GO PUBLIC DI BURSA EFEK INDONESIA PERIODE 2012-2014
}

\author{
Dhita Hariani Br Tarigan \\ Romasi Luman Gaol
}

\begin{abstract}
Abstrak
Penelitian ini bertujuan untuk mengetahui dan menganalisis pengaruh pengumuman merger dan akuisisi terhadap reasksi pasar yang diukur dengan perubahan harga saham, return saham, return ekspektasi dan abnormal return saham pada perusahaan go public di Bursa Efek Indonesia periode 2012-2014. Perusahaan sampel yang di uji dalam penelitian ini adalah 46perusahaan dari berbagai jenis industri yang berbeda-beda yang melakukan merger dan akuisisi selama periode 2012-2014.Teknik pengambilan sampel yang digunakan adalah purposive sampling.Data diperoleh dari Bursa Efek Indonesia tahun 2012 sampai dengan 2014.Pengujian hipotesis yang digunakan adalah One sample t-test dan Paired sample t-testdengan tingkat signifikansi sebesar 5\%.Dari hasil pengujian diperolehbahwa perusahaan pengakuisisitidak memperoleh tambahan kemakmuran dari aktivitas merger dan akuisisi. Hasil penelitian juga menunjukkan bahwa secara statistik tidak terdapat perbedaan yang signifikan antara rata-rata abnormalreturnsebelum dan sesudah pengumuman merger dan akuisisi.
\end{abstract}

Kata kunci : Merger, Akuisisi, Harga Saham, Return Saham, Return Ekspektasi, Abnormal Return

\section{PENDAHULUAN}

Strategi yang dapat dilakukan perusahaan agar dapat mempertahankan eksistensinya dan memperbaiki kinerjanya, adalah melalui penggabungan usaha atau yang biasa disebut merger dan akuisisi (takeover).Tujuan perusahaan dalam melakukan merger dan akuisisiadalah untuk meningkatkan dana guna melakukan ekspansi.

Pengumuman merger dan akuisisi adalah informasi yang sangat penting dalam suatu industri, karena dua perusahaan akan menyatukan kekuatannya. Secara teori, setelah merger dan akuisisi ukuran perusahaan dengan sendirinya bertambah besar karena aset dan kewajiban perusahaan digabung bersama. Dasar logis dari pengukuran berdasarkan akuntansi adalah bahwa jika ukuran bertambah besar ditambah dengan sinergi yang dihasilkan dari aktivitas-aktivitas yang simultan, maka laba perusahaan juga akan semakin meningkat. Oleh karena itu, kinerja pasca merger dan akuisisi seharusnya semakin baik dibandingkan dengan sebelum merger dan akuisisi (Usadha dan Gerianta, 2008).

Keputusan merger dan akuisisi merupakan keputusan penting dan sangat mendasar karena dapat bersifat positif maupun dapat merugikan banyak orang. 
Adanya reaksi pasar, baik reaksi positif maupun negatif terhadap kejadian merger dan akuisisi tergantung dari ketersediaan informasi bagi investor pada waktu pengumuman merger dan akuisisi tersebut.

Perilaku dan perubahan harga selama pengumuman merger dan akuisisi merefleksikan gabungan semua informasi dan pengaruh yang dikeluarkan dalam pengumuman merger dan akuisisi (Halpern, 1983). Dengan demikian, pengumuman merger dan akuisisi sebagai suatu informasi dapat berpengaruh tidak hanya pada kedua perusahaan yangmelakukan merger dan akusisi yaitu perusahaan pengakuisisi (acquiring firm/ akuisitor) dan perusahaan yang diakuisisi (target firm), namun perusahaan lain yang menjadi pesaing yang berada dalam satu jenis industri yang sama dengan akuisitor dan target firm.

Pasar modal yang efisien adalah jika semua investor akan menerima dan mengevaluasi informasi yang berkaitan dengan harga saham pada waktu yang hampir sama. Dengan demikian, harga saham akan menyesuaikan dengan segera dan mencerminkan adanya informasi yang relevan.

Penelitian ini akan menguji apakah informasi pengumuman penggabungan usaha mampu memberikan informasi yang relevan, sehingga dapat digunakan oleh para investor dalam pengambilan keputusan investasi dan adakah bukti empiris bahwa pengumuman merger dan akuisisi memberikan peranan penting di pasar modal yang tercemin lewat reaksi pasar berupa adanya return saham dan abnormal return sebelum dan sesudah pengumuman penggabungan usaha. Dari latar belakang diatas, maka perumusan masalah yang dikemukakan pada penelitian ini adalah :

1. Apakah terdapat rata - rata abnormal return yang signifikan di seputar pengumuman merger dan akuisisi

2. Apakah terdapat perbedaan yang signifikan rata - rata abnormal return pada periode sebelum dan sesudah pengumuman merger dan akuisisi?

\section{TINJAUAN PUSTAKA}

\section{Penggabungan Usaha}

Penggabungan usaha adalah alternatif bagi perusahaan dalam rangka melakukan pengembangan usaha secara eksternal guna mempertahankan kelangsungan hidup dan untuk tujuan pertumbuhan perusahaan. Ikatan Akuntan Indonesia dalam Pernyataan Standar Akuntansi Keuangan Nomor 22 tentang Akuntansi Penggabungan Usaha, yang berlaku efektif sejak 1 Januari 1995 . Pada paragraf 08 mendefinisikan penggabungan badan usaha sebagai bentuk pernyataan dua atau lebih perusahaan yang terpisah menjadi satu entitas ekonomi, karena satu perusahaan menyatu dengan (uniting with) perusahaan lain ataupun memperoleh kendali (control) atas aktiva dan operasi perusahaan lain (IAI, 2004: 22.2).

\section{Merger}

Merger adalah sebagai bentuk dari penggabungan usaha, yang merupakan penyatuan dua atau lebih perusahaan yang terpisah menjadi satu entitas ekonomi 
karena satu perusahaan menyatu dengan perusahaan lain atau memperoleh kendali atas aset dan operasi perusahaan lain.

Setelah terjadinya merger, perusahaan yangdiambil alih dibubarkan atau dilikuidasi sedangkan perusahaan yangmengambil alih tetap beroperasi secara hukum sebagi suatu badanusaha dan melanjutkan kegiatan perusahaan yang diambil alih(Foster,1994).

Dalam PSAK No. 22 dinyatakan bahwa penggabungan usaha dapat mengakibatkan terjadinya legal merger. Suatu legal merger biasanya merupakan merger dua badan usaha melalui salah satu cara berikut :

a) Asset, dan kewajiban dari suatu perusahaan dialihkan ke perusahaan lain dan perusahaan yang melakukan pengalihan tersebut dibubarkan, atau

b) Asset dan kewajiban dari dua atau lebih perusahaan dialihkan ke perusahaan baru dan kedua perusahaan yang melakukan pengalihan tersebut dibubarkan.

\section{Akuisisi}

Akuisisi merupakan suatu bentuk pengambilalihan kepemilikan atau pengendalian atas saham atau aset suatu perusahaan oleh perusahaan lain, dan dalam peristiwa ini baik perusahaan pengambilalih atau yang diambilalih tetap berdiri sebagai badan hukum yang terpisah. Bila ditinjau menurut PSAK (2004) No. 22 mendefinisikan Akuisisi (acquisiton) adalah suatu penggabungan usaha di mana salah satu perusahaan, yaitu pengakuisisi (acquirer) memperoleh kendali atas aktiva neto dan operasi perusahaan yang diakuisisi (acquiree), dengan memberikan aktiva tertentu, mengakui suatu kewajiban, atau mengeluarkan saham.

Akuisisi dapat dibedakan menjadi akuisisi saham dan akuisisi asset. Akuisisi sahammerupakan pengambil-alihan atau pembelian saham suatu perusahaan dengan menggunakan kas, saham atau sekuritas lain. Akuisisi saham biasanya melaui tahappenawaran (tender offer) oleh perusahaan penawar (bidder firm) kepada parapemegang saham perusahaan target. Akuisisi ini tidak membutuhkan persetujuanpihak manajemen dan dapat dilakukan meskipun pihak manajemen tidak menyetujuipembelian saham perusahaan. Oleh karena itu akuisisi ini disebut bentuk pengambilalihan yang tidak besahabat (hostile takeover).Sedangkan akuisisi asset dilakukandengan cara membekukan sebagian aset perusahaan target oleh perusahaanpengakuisisi. Akuisisi jenis ini membutuhkan suara pemegang saham perusahaantarget untuk menyetujui pengambil-alihan perusahaan tersebut (Rachmawati danTanderlilin, 2000).Berdasarkan pengertian diatas, proses akuisisi dapat digambarkan sebagai berikut ini. 


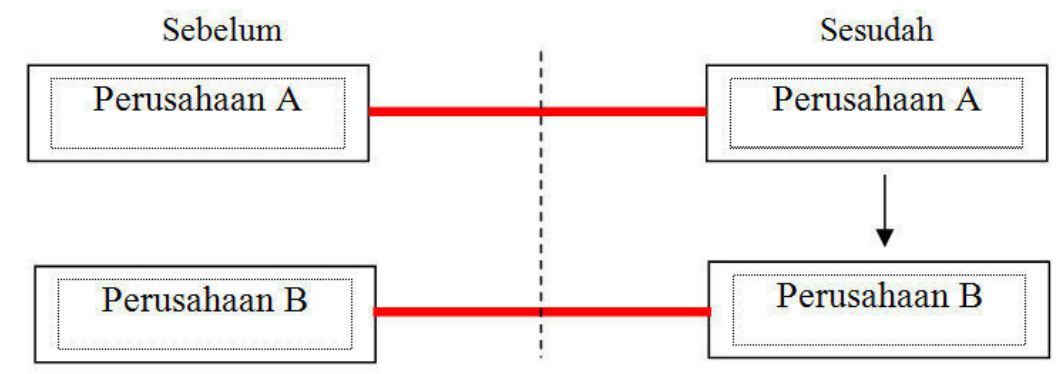

\section{Signaling Theory}

Menurut Wolk, et al. (2001) signaling theory menjelaskan alasan perusahaan menyajikan informasi untuk pasar modal. Signaling theory menunjukkan adanya asimetri informasi antara manajemen perusahaan dan pihak-pihak yang berkepentingan dengan informasi tersebut.Signaling theory mengemukakan tentang bagaimana seharusnya perusahaan memberikan sinyal-sinyal pada pengguna laporan keuangan.

Menurut Jama'an (2008) signaling theory mengemukakan tentang bagaimana seharusnya sebuah perusahaan memberikan sinyal kepada pengguna laporan keuangan. Sinyal ini berupa informasi mengenai apa yang sudah dilakukan oleh manajemen untuk merealisasikan keinginan pemilik. Sinyal dapat berupa promosi atau informasi lain yang menyatakan bahwa perusahaan tersebut lebih baik daripada perusahaan lain. Signaling theory menjelaskan bahwa pemberian sinyal dilakukan oleh manajer untuk mengurangi asimetri informasi.

Manajer memberikan informasi melalui laporan keuangan bahwa mereka menerapkan kebijakan akuntansi konservatisme yang menghasilkan laba yang lebih berkualitas karena prinsip ini mencegah perusahaan melakukan tindakan membesar-besarkan laba dan membantu pengguna laporan keuangan dengan menyajikan laba dan aktiva yang tidak overstate.

Signaling theory juga dapat membantu pihak perusahaan (agent), pemilik, dan pihak luar perusahaan mengurangi asimetri informasi dengan menghasilkan kualitas atau integritas informasi laporan keuangan. Untuk memastikan pihakpihak yang berkepentingan meyakini keandalan informasi keuangan yang disampaikan pihak perusahaan (agent), perlu mendapatkan opini dari pihak lain yang bebas memberikan pendapat tentang laporan keuangan (Jama'an, 2008).

\section{Event Study}

Studi peristiwa menyelidiki respon pasar terhadap kandungan informasi dari suatu pengumuman atau publikasi peristiwa tertentu.Kandungan informasi dapat berupa berita baik (good news) atau berita buruk (bad news). Hipotesis pasar efisien memprediksikan bahwa pasar akan memberikan respon pasar positif untuk berita baik, dan respon negatif untuk berita buruk. Respon pasar tersebut tercermin dari abnormal return positif (berita baik) dan abnormal return negatif 
(berita buruk). Jika pasar meragukan kebenaran suatu informasi, maka akan terjadi respon yang terlambat atau terdahulu karena ada investor yang lebih menunggu hingga waktu tertentu.

Studi peristiwa berusaha mendeteksi respon pasar terhadap suatu peristiwa yang dipublikasikan.Respon pasar tergantung dari kandungan informasi yang melekat dalam suatu peristiwa yang diduga berdampak pada aliran kas perusahaan dimasa mendatang.Pengujian respon pasar terkait dengan hipotesis efisiensi informasi (kecepatan respon pasar) dan hipotesis efisiensi keputusan (ketepatan respon pasar). Kecepatan respon pasar disini bearti reaksi pasar bersifat segera dan serentak, artinya abnormal return (signifikan) hanya terjadi pada satu atau dua spot waktu seputar pengumuman peristiwa. Abnormal return (signifikan) yang terjadi pada semua spot waktu diseputar pengumuman peristiwa mengindikasikan pasar bereaksi berkepanjangan dan justru menunjukkan tidak efisien, karena terdapat pelaku pasar yang bereaksi terlalu cepat atau terlalu lambat terhadap suatu informasi.

Sebaliknya, bila tidak terdapat abnormal return pada semua spot waktu di seputar pengumuman peristiwa menunjukkan bahwa pasar tidak bereaksi atau tidak mempercayai kandungan informasi sari suatu peristiwa yang diumumkan. Ketepatan respon pasar terkait dengan apakah pasar bereaksi dengan benar.Hal ini di indikasikan dengan arah respon pasar bersifat positif atau negatif. Indikator tersebut tampak dari abnormal return positif untuk good news dan abnormalreturn negatif untuk bad news. Reaksi pasar secara benar hanya terjadi bilainvestor memiliki pengetahuan yang benar tentang suatu peristiwa sehingga ia dapat membuat keputusan yang benar (tepat).

\section{Return Saham}

Return merupakan hasil yang diperoleh dari investasi. Return dapatberupa return realisasi yang sudah terjadi atau return ekspektasi yang belum terjadi tetapi yang diharapkan akan terjadi di masa datang (Jogiyanto, 2000:107).

Berdasarkan jenisnya, return saham dibagi 2, yaitu (Jogiyanto, 2000)

(1) Return realisasi (realized return), yaitu return yangsudah terjadi. Return realisasi dihitung berdasarkan data historis.Return realisasi penting karena digunakan sebagai salah satupengukur kinerja dari perusahaan. Terdapat beberapa pengukuran realisasi seperti return total (total return), relatif return (return relative), kumulatifreturn (return kumulatif) dan return disesuaikan (adjusted return). Namun dalam penelitian iniyang menjadi pokok dari return realisasi adalah bahwa return yang sesungguhnya terjadi dalam suatu investasi itu yang dinamakan return realisasi.

(2) Return Ekspektasi (expected return), merupakan return yangdiharapkan akan diperoleh oleh investor dimasa mendatang. Berbeda dengan return realisasi yang sifatnya sudah terjadi, return ekspektasi sifatnya belum terjadi. Dalam melakukan investasi akan selalu terkandung resiko, dengan adanya risiko atau ketidakpastian, maka investor tidak dapat menentukan secara pasti besar 
keuntungan yang akan diperoleh dimasa depan.

\section{Abnormal Return}

Abnormal return atau excess return merupakan kelebihan dari return yangsesungguhnya terjadi (actual return) terhadap return normal. Return normal merupakan excpected return (return yang diharapkan oleh investor). Abnormalreturn terdiri dari dua macam yaitu abnormal return positif dan abnormal return negatiif.Abnormal return positif menunjukan adanyal sinyal positif atau kabarbaik dari suatu pengumuman. Abnormal return positif terjadi jika return realisasi lebih besar dari pada return yang diharapkan. Sedangkan abnormal return negatif atau kabar buruk dari suatu pengumuman.Abnormal return negatif terjadi bila return realisasi lebih kecil daripada return yang diharapkan (Jogiyanto, 2003).

Jika suatu pengumuman yang dipublikasikan di pasar modal mengandung suatu informasi (information content), maka akan terjadi reaksi pasar. Reaksi pasar dapat ditunjukan dengan adanya perubahan harga saham dari sekuritas yang bersangkutan.Reaksi pasar yang terjadi tersebut dapat diukur dengan menggunakan abnormal return.Abnormal Return dihitung dengan Market Adjusted Abnormal Return, yaitu merupakan selisih return saham yang dihitung dari return individual dikurangi return ekspektasi.

$$
\begin{aligned}
& A R_{i . t}=R_{i . t}-R_{m t} \\
& \text { Dimana: } \\
& A R_{i . t} \quad=\text { abnormal return saham i pada saat } \mathrm{t} \\
& R_{i . t} \quad=\text { return saham perusahaan i pada periode peristiwa ke } \mathrm{t} \\
& R_{m t} \quad=\text { return ekspektasi pada saat } \mathrm{t}
\end{aligned}
$$

\section{Pengaruh Merger dan Akuisisi Terhadap Abnormal Return}

Kinerja perusahaan pasca-akuisisi atau merger bisa diidentifikasi melalui laporan keuangan dalam beberapa tahun setelah penggabungan. Namun teori keuangan modern memberikan justifikasi bahwa cara yang paling reliable dalam mengukur kinerja keuangan ekonomi perusahaan adalah dengan melacak harga sahamnya terhadap kinerja pasar secara keseluruhan. Dalam pasar yang efisien, nilai yang diharapkan dari sebuah akuisisi akan diestimasi dengan menganalisis perubahan pasar segera setelah pengumuman transaksi akuisisi. Pengujian seperti ini biasa menggunakan abnormal return (Moin, 2004:298).

Abnormal return sebenarnya merupakan sebuah metodologiuntuk meneliti atau menguji pengaruh kandungan informasi terhadap reaksi pasar saham.Metodologi menggunakan "event study" bertujuan untuk menguji apakah suatu peristiwa (event) berpengaruh terhadap harga saham dengan mengambil waktu spesifik diseputar tanggal pengumuman tersebut.

Jika pengumuman merger dan akuisisi berpengaruh secara signifikan terhadap pergerakan harga saham atau abnormal return berarti pengumuman tersebut 
mengandung informasi (informationalcontent). Apabila diperoleh abnormal return yang positif berartiterdapat peningkatan kemakmuran pemegang saham, dan sebaliknya jika abnormal return bernilai negatif berarti terjadi penurunan kemakmuran. Di sisi lain, apabila pengumuman merger dan akuisisi tersebut tidak menghasilkan abnormal return (abnormal returnsama dengan nol) berarti akuisisi tidak berpengaruh terhadap kemakmuran pemegang saham.

Perubahan kemakmuran pemegang saham inilah yang ingin diukur dengan menggunakan abnormal return yaitu dengan membandingkan antara keuntungan yang sesungguhnya (actual return) dengan keuntungan yang diharapkan (expected return).

\section{Hipotesis}

Hipotesis adalah jawaban sementara dari suatu masalah yang masih harus diuji kebenarannya. Berdasarkan perumusan masalah diatas, maka penulis merumuskan hipotesisnya sebagai berikut :

H1 : Terdapat rata-rataharga saham, return saham, return ekspektasi, danabnormal return saham yang signifikan diseputar pengumumanmerger dan akuisisi.

H2 : Terdapat perbedaan harga saham, return saham, return ekspektasi, dan abnormal return saham sebelum dan sesudah pengumuman merger dan akuisisi.

\section{METODE PENELITIAN}

\section{Populasi dan Sampel}

Populasi dalam penelitian ini adalahperusahaan go public yang terdaftar di BEI antara tahun 2012-2014.Sampel dalam penelitian ini berasal dari semua jenis perusahaan atau bersifat umum. Pemilihan sampel digunakan dengan metode purposive sampling yaitu penentuan sampel berdasarkan kriteria yang telah ditentukan (judgement sampling).Penelitian ini merupakan penelitian penjelas (Explanatory Research) yang menyoroti hubungan antara variabel penelitian dan menguji hipotesis yang dirumuskan. Adapun kriteria saham perusahaan yang dijadikan sampel adalah sebagai berikut:

1. Sampel adalah perusahaan pengakuisisi dari tiap jenis perusahaanyang terdaftar di BEI dan melakukan aktivitas merger dan akuisisiantara tahun 2012-2014.

2. Melakukan aktivitas merger dan akuisisi pada periode 2012-2014.

3. Mempunyai kelengkapan informasi kegiatan merger dan akuisisi seperti tanggal akuisisi dan harga penutupan saham selama 10 hari sebelum dan sesudah pengumuman merger dan akuisisi.

4. Tidak melakukan corporate action lain selama event window,karena dikhawatirkan akan menyebabkan hasil analisis yang bias. 


\section{Operasionalisasi Variabel}

Penelitian ini menganalisis secara empiris tentang pengukuran abnormal return saham sebelum dan sesudah pengumuman merger dan akuisisi. Akan dilakukan pengujian atas hipotesis-hipotesis yang telah diajukan.Pengujian hipotesis dilakukan menurut metode penelitian dan analisis yang dirancang sesuai dengan variabel-variabel yang diteliti agar mendapatkan hasil yang akurat.

\section{a. Return Realisasi (Realized Return)}

Menurut Jogiyanto (2003),returnrealisasi (realized return) merupakan returnyang telah terjadi. Return realisasi dapat dihitung dengan rumus :

$$
R_{i . t}=\frac{P_{i . t}-P_{i . t-1}}{P_{i . t-1}}
$$

Dimana :

$\mathrm{R}_{\mathrm{i.t}} \quad=$ Return saham perusahaan i pada waktu $\mathrm{t}$.

$\mathrm{P}_{\mathrm{i} . \mathrm{t}} \quad=$ Harga saham perusahaan i pada waktu $\mathrm{t}$.

$\mathrm{P}_{\mathrm{i} . \mathrm{t}-1} \quad$ = Harga saham perusahaan i sebelum waktu $\mathrm{t}$.

\section{b. Return Ekspektasi(Expected Return)}

Menurut Jogiyanto (2003), return ekspektasi (expected return) adalah return yang diharapkan akan diperoleh investor di masa yang akan datang. Return ekspektasi dapat dihitung dengan rumus :

$$
R_{m t}=\frac{I H S G_{t}-I H S G_{t-1}}{I H S G_{t-1}}
$$

Dimana :

$\mathrm{R}_{\mathrm{mt}} \quad=$ Return Ekspektasi

$\mathrm{IHSG}_{\mathrm{t}}=$ Indeks Harga Saham Gabungan pada ke $\mathrm{t}$

$\mathrm{IHSG}_{\mathrm{t}-1}=$ Indeks Harga Saham Gabungan pada ke $\mathrm{t}-1$

\section{c. Abnormal return}

Abnormal return merupakan selisih antara actual return dengan expected return, yaitu kelebihan dari return yang sesungguhnya terjadi terhadap return ekspektasi (return yang diharapkan oleh investor). Abnormal Return dihitung dengan Market Adjusted Abnormal Return, yaitu merupakan selisih return saham yang dihitung dari return individual dikurangi return ekspektasi (Jogiyanto, 2000). Secara matematis abnormal return dapat dihitung sebagai berikut :

$\mathrm{AR}_{\mathrm{i} . \mathrm{t}}=\mathrm{R}_{\mathrm{i} . \mathrm{t}}-\mathrm{R}_{\mathrm{mt}}$ 
Dimana:

$\mathrm{AR}_{\mathrm{i} . \mathrm{t}} \quad=$ abnormal return saham i pada saat $\mathrm{t}$

$\mathrm{R}_{\mathrm{i} . \mathrm{t}} \quad=$ return saham perusahaan i pada periode peristiwa ke $\mathrm{t}$

$\mathrm{R}_{\mathrm{mt}} \quad=$ return ekspektasi pada saat $\mathrm{t}$

\section{Teknik Analisis Data}

Dalam penelitian ini digunakan beberapa metode untuk mengukur dan membandingkan abnormal return sebelum dan sesudah melakukan merger.

\section{a. Analisis Deskriptif}

Analisis deskriptif adalah analisis yang menekankan pada pembahasan datadata dan subjek penelitian dengan menyajikan data-data secara sistematik dan tidak menyimpulkan hasil penelitian (Priyatno,2008).

a. Periode waktu yang digunakan dalam penelitian ini yaitu periode peristiwa (event period) selama 20 hari, periode peristiwa ini dibagi menjadi dua bagian, yaitu 10 hari sebelum pengumuman (event day), dan 10 hari setelah pengumuman (event day).

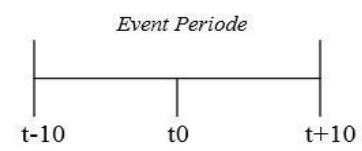

b. Menghitung actual return dari masing-masing saham perusahaan akuisitor dalam kurun waktu 20 hari yaitu 10 hari sebelum tanggal pengumuman dan 10 hari setelah tanggal pengumuman merger dan akuisisi dengan rumus :

$$
R_{i . t}=\frac{P_{i . t}-P_{i . t-1}}{P_{i . t-1}}
$$

Dimana:

$\mathrm{R}_{\mathrm{i} . \mathrm{t}}=$ return saham i pada saat $\mathrm{t}$

$\mathrm{P}_{\mathrm{i} . \mathrm{t}} \quad=$ harga saham i pada saat $\mathrm{t}$

$\mathrm{P}_{\mathrm{i} . \mathrm{t}-1} \quad=$ harga saham $\mathrm{i}$ pada saat $\mathrm{t}-1$

c. Menghitung return ekspektasi selama periode peristiwa dengan rumus :

$$
\mathrm{R}_{\mathrm{mt}}=\frac{I H S G_{t}-I H S G_{t-1}}{I H S G_{t-1}}
$$

Dimana:

$\mathrm{R}_{\mathrm{mt}} \quad=$ Return Ekspektasi

$\mathrm{IHSG}_{\mathrm{t}}=$ Indeks Harga Saham Gabungan pada ke t

$\mathrm{IHSG}_{\mathrm{t}-1}=$ Indeks Harga Saham Gabungan pada ke t-1

d. MenghitungAbnormal Return (AR) dengan rumus :

$$
\mathrm{AR}_{\mathrm{i} . \mathrm{t}} \quad=\mathrm{R}_{\mathrm{i} . \mathrm{t}}-\mathrm{R}_{\mathrm{mt}}
$$


Dimana:

$\mathrm{AR}_{\mathrm{it}} \quad=$ abnormal return saham i pada saat $\mathrm{t}$

$\mathrm{R}_{\mathrm{i} . \mathrm{t}}=$ return saham perusahaan i pada periode peristiwa ke $\mathrm{t}$

$\mathrm{R}_{\mathrm{mt}} \quad=$ return ekspektasi pada saat $\mathrm{t}$

e. Menghitung rata-rata abnormal return saham pada hari ke $t$ dengan rumus :

$$
A A R_{n t}=\frac{\left(\sum_{i=1}^{n} A R_{i t}\right)}{n}
$$

Dimana:

$\begin{array}{ll}\mathrm{ARR}_{\mathrm{nt}} & =\text { rata-rata abnormal return saham pada saat } \mathrm{t} \\ \mathrm{AR}_{\mathrm{it}} & =\text { abnormal return saham } \\ \mathrm{n} & =\text { jumlah hari yang diteliti }\end{array}$

\section{b. Uji Normalitas}

Uji normalitas digunakan untuk mengetahui apakah data yang digunakan berdistribusi normal atau tidak.Angka statistik yang semakin kecil nilainya, menunjukkan distribusi data semakin normal.Salah satu penyebab yang menjadikan data tidak berdistribusi normal adalah karena terdapat beberapa item data yang bersifat outliers, yaitu kasus atau data yang memiliki karakteristik unik yang terlihat sangat berbeda jauh dari obserasi-observasi lainnya dan muncul dalam bentuk nilai ekstrim baik untuk sebuah variabel tunggal atau variabel kombinasi (Ghozali, 2005).

\section{c. Uji One Sample T-Test}

Untuk menguji hipotesis 1 digunakanuji one sample t-test untuk melihat signifikansi dari harga saham, return saham, return ekspektasi, dan abnormal return saham di sekitar tanggal pengumuman merger dan akuisisi. One sample ttest merupakan uji statistik yang digunakan untuk menguji hipotesis rata-rata suatu populasi (Ghozali, 2009).

\section{d. Uji Paired Sample T-Test}

Paired Sample T-Testatau lebih dikenal dengan pre post design adalah analisis dengan melibatkan dua pengukuran pada subyek yang sama terhadap suatu pengaruh atau perlakuan tertentu. Pengukuran pertama dilakukan sebelumdiberi perlakuan tertentu dan pengukuran kedua dilakukan sesudahnya. Dasar pemikirannya sederhana, yaitu bahwa apabila suatu perlakuan tidak memberi pengaruh maka perbedaan rata-rata adalah nol (Cornelius Trihendradi, 2005). 


\section{HASIL PENELITIAN DAN PEMBAHASAN}

\section{Statistik Deskriptif}

Tabel. 1. Statistik Deskriptif Return Saham Pada Event Window

\begin{tabular}{|c|c|c|c|}
\hline Periode & Minimum & Maksimum & Rata-Rata \\
\hline $\mathrm{t}-10$ & $-0,058815$ & 0,129412 & 0,00816491 \\
\hline $\mathrm{t}-9$ & $-0,083739$ & 0,049368 & $-0,00164711$ \\
\hline $\mathrm{t}-8$ & $-0,054943$ & 0,236563 & 0,00737841 \\
\hline $\mathrm{t}-7$ & $-0,068966$ & 0,165213 & $-0,00376857$ \\
\hline $\mathrm{t}-6$ & $-0,059701$ & 0,089880 & 0,00544676 \\
\hline $\mathrm{t}-5$ & $-0,051020$ & 0,073176 & 0,00358850 \\
\hline $\mathrm{t}-4$ & $-0,103449$ & 0,053812 & $-0,00540880$ \\
\hline $\mathrm{t}-3$ & $-0,038468$ & 0,232152 & 0,00265091 \\
\hline $\mathrm{t}-2$ & $-0,031250$ & 0,130428 & 0,00319052 \\
\hline $\mathrm{t}-1$ & $-0,074074$ & 0,053097 & $-0,00098860$ \\
\hline t 0 & $-0,049425$ & 0,062495 & 0,00521342 \\
\hline $\mathrm{t} 1$ & $-0,065421$ & 0,035296 & $-0,00374311$ \\
\hline t 2 & $-0,040003$ & 0,045872 & $-0,00068713$ \\
\hline t 3 & $-0,044882$ & 0,073684 & 0,00222476 \\
\hline t 4 & $-0,046154$ & 0,031917 & $-0,00143946$ \\
\hline t 5 & $-0,030010$ & 0,094114 & 0,00719733 \\
\hline t 6 & $-0,045685$ & 0,052083 & $-0,00086602$ \\
\hline $\mathrm{t} 7$ & $-0,047619$ & 0,102041 & 0,00462017 \\
\hline t 8 & $-0,041236$ & 0,074376 & $-0,00264283$ \\
\hline t 9 & $-0,032257$ & 0,048780 & 0,00098798 \\
\hline t 10 & 0,000000 & 0,000000 & 0,00000000 \\
\hline
\end{tabular}

Sumber: data sekunder yang diolah, 2016

Tabel di atas menunjukkanbahwa rata-rata return saham sebelum pengumuman merger dan akuisisi menghasilkan rata-rata return saham yang negatif selama 4 hari yaitu pada t-9, t-7, t-4, dan t-1. Sedangkan sesudah pengumuman merger dan akuisisi, dihasilkan rata-rata return saham yang bernilai negatif sebanyak 5 hari yaitu pada $\mathrm{t} 1, \mathrm{t} 2$, t $4, \mathrm{t} 6$, dan $\mathrm{t} 8$. Hal ini mengindikasikan telah terjadi penurunan terhadap returnsaham sesudah pengumuman. Penurunan return saham sesudah pengumuman tersebut kemungkinan disebabkan para investor tidak mau spekulatif dalam memegang/ mendapatkan saham, hal ini disebabkan ketidaktahuannya mengenai motif/ motivasi perusahaan dalam melakukan merger dan akuisisi, apakah menyangkut motif ekonomi (adanya target pada keunggulan kompetitif) atau motif non ekonomi (perusahaan sudah lemah secara modal dan keterampilan manajemen). 
Penurunan return saham sesudah pengumuman kemungkinan juga disebabkan informasi marger dan akuisisi direspon oleh investor sebagai informasi yang tidak dapat memberikan keuntungan atau kemungkinan merupakan berita buruk (bad news) sehingga ketertarikan investor terhadap saham menurun, dengan tidak adanya ketertarikan terhadap saham tersebut harga saham berangsur-angsur menjadi turun dan berdampak pada menurunnya return saham tersebut.

Tabel. 2. Statistik Deskriptif Return Ekspektasi Pada Event Window

\begin{tabular}{cccc}
\hline Periode & Minimum & Maksimum & Rata-Rata \\
\hline t - 10 & 0,000000 & 0,000000 & 0,00000000 \\
t -9 & $-0,055844$ & 0,020707 & 0,00382387 \\
t -8 & $-0,036755$ & 0,033527 & 0,00012922 \\
t - & $-0,027252$ & 0,033223 & 0,00163526 \\
t -6 & $-0,022374$ & 0,017494 & $-0,00244528$ \\
t -5 & $-0,019193$ & 0,046486 & 0,00403302 \\
t -4 & $-0,038210$ & 0,038213 & $-0,00060672$ \\
t -3 & $-0,037089$ & 0,022157 & $-0,00054622$ \\
t -2 & $-0,024756$ & 0,033204 & $-0,00009004$ \\
t - & $-0,027173$ & 0,029199 & $-0,00088324$ \\
t 0 & $-0,018077$ & 0,039816 & 0,00141480 \\
t 1 & $-0,035044$ & 0,038213 & 0,00077791 \\
t 2 & $-0,027252$ & 0,019186 & $-0,00161430$ \\
t 3 & $-0,021746$ & 0,030615 & 0,00009235 \\
t 4 & $-0,036756$ & 0,033527 & 0,00180643 \\
t 5 & $-0,011055$ & 0,022157 & 0,00291280 \\
t 6 & $-0,032049$ & 0,029199 & 0,00146370 \\
t $~$ & $-0,027173$ & 0,046486 & 0,00396167 \\
t 8 & $-0,036755$ & 0,034490 & $-0,00102948$ \\
t 9 & $-0,036756$ & 0,017673 & $-0,00182533$ \\
t 10 & 0,000000 & 0,000000 & 0,00000000 \\
\hline
\end{tabular}

Sumber: data sekunder yang diolah, 2016

Tabeldi atas menunjukkanbahwa pengumuman merger dan akuisisi ternyata mampu menghasilkan rata-rata return ekspektasi yang positif. Nilai rata-rata (mean) return ekspektasi sesudah pengumuman lebih tinggi daripada sebelum pengumuman. Hal ini ditunjukkkan dengan return ekspektasi sebelum pengumuman bernilai negatif sebanyak 5 hari sedangkan, sesudah pengumuman rata-rata return ekspektasi yang bernilai negatif hanya 3 hari. Hal ini menunjukkan bahwa informasi tentang pengumuman merger dan akuisisi merupakan informasi yang cukup bernilai dan merupakan sinyal positif bagi investor dalam mengambil keputusan. 
Tabel. 3. Statistik Deskriptif AAR Pada Event Window

\begin{tabular}{llll}
\hline Periode & Minimum & Maksimum & Rata-Rata \\
\hline t -10 & 0,000000 & 0,000000 & 0,00000000 \\
t -9 & $-0,077407$ & 0,114633 & 0,00434115 \\
t -8 & $-0,076331$ & 0,054436 & $-0,00177626$ \\
t -7 & $-0,054392$ & 0,232930 & 0,00574330 \\
t -6 & $-0,071856$ & 0,161490 & $-0,00132320$ \\
t -5 & $-0,042400$ & 0,084984 & 0,00141376 \\
t -4 & $-0,038281$ & 0,094922 & 0,00419524 \\
t -3 & $-0,066361$ & 0,047384 & $-0,00486257$ \\
t - & $-0,054810$ & 0,241583 & 0,00274089 \\
t -1 & $-0,025495$ & 0,125349 & 0,00407374 \\
t 0 & $-0,078923$ & 0,064587 & $-0,00238193$ \\
t 1 & $-0,039688$ & 0,069909 & 0,00432224 \\
t 2 & $-0,056971$ & 0,035332 & $-0,00212887$ \\
t 3 & $-0,044602$ & 0,042459 & $-0,00077957$ \\
t 4 & $-0,055949$ & 0,074690 & 0,00041839 \\
t 5 & $-0,038845$ & 0,027903 & $-0,00435222$ \\
t 6 & $-0,033800$ & 0,080301 & 0,00573352 \\
t 7 & $-0,047000$ & 0,044952 & $-0,00482765$ \\
t 8 & $-0,041427$ & 0,114759 & 0,00564961 \\
t 9 & $-0,039792$ & 0,064773 & $-0,00081752$ \\
t 10 & $-0,037239$ & 0,038895 & 0,00033987 \\
\hline S &
\end{tabular}

Sumber: data sekunder yang diolah, 2016

Tabel diatas menunjukkanbahwa pengumuman merger dan akuisisi ternyata mampu menghasilkan rata-rata abnormal return yang positif. Selama 21 hari periode pengamatan ( $\mathrm{t}-10$ sampai $\mathrm{t} 10)$, diperoleh rata-rata abnormal return bernilai positif selama 12 hari $(57,14 \%)$ dan dihasilkan rata-rata abnormal return bernilai negatif sebanyak 9 hari $(42,86 \%)$. Hasil ini menunjukkan bahwa secara umum keputusan perusahaan untuk melakukan kegiatan merger dan akuisisi direspon positif oleh investor, adanya harapan akan kinerja perusahaan yang lebih baik di masa yang akan datang menyebabkan kenaikan permintaan terhadap saham- saham perusahaan tersebut.

\section{Uji Normalitas}

Untuk menentukan alat uji statistik yang tepat bagi hipotesisyang dibuat, maka terlebih dahulu dilakukan uji normalitas datadengan menggunakan One Sample Kolmogorov Smirnov Test denganprobabilitas sebesar lima persen. Hasil pegujiannya adalah sebagaiberikut ini. 
Tabel. 4. Hasil Uji Normalitas Data One-Sample Kolmogorov-Smirnov Test

\begin{tabular}{|ll|l|l|}
\hline & & $\begin{array}{c}\text { Abnormal Return } \\
10 \text { hari sebelum }\end{array}$ & $\begin{array}{l}\text { Abnormal Return } \\
10 \text { hari sesudah }\end{array}$ \\
\hline $\mathrm{N}$ & Mean & 46 & 46 \\
Normal Parameters & $\mathrm{a}, \mathrm{b}$ &, 00161613 &, 00036843 \\
& Std. Deviation &, 009427387 &, 005887422 \\
& Absolute &, 185 &, 144 \\
Most Extreme Differences & Positive &, 185 &, 144 \\
& Negative &,- 141 &,- 087 \\
Kolmogorov-Smirnov Z & & 1,258 &, 974 \\
Asymp. Sig. (2-tailed) &, 085 &, 299 \\
\hline
\end{tabular}

a. Test distribution is Normal.

b. Calculated from data.

Sumber: data sekunder yang diolah, 2016

Tabel 4 di atas menunjukkan bahwa nilai asymptotic significance adalah sebesar 0,299 yang lebih besar dari 0.05, baik padapengujian terhadap AAR Sebelum dan AAR Sesudah. Atas dasar hasilpengujian ini, maka dapat disimpulkan bahwa data berdistribusinormal. Oleh karena data penelitian terdistribusi normal, maka dalampengujian hipotesis kedua dalam penelitian ini menggunakan alat uji one sample t-test dan uji paired sample t-test.

\section{Hasil Pengujian Hipotesis I}

Pengujian Hipotesis I ini bertujuan untuk membuktikan apakah pengumuman merger dan akuisisi direspon oleh pasar, sehingga menghasilkan nilai return saham, return ekspektasi danabnormal returnsaham dengan nilai signifikan minimum $\alpha=5 \%$. Uji dilakukan dengan menggunakan tehnik analisis One sample t-test.

Tabel.5. Hasil Uji-t Pada Rata-Rata Return Saham Selama Event Window

\begin{tabular}{rrrc}
\hline Periode & \multicolumn{1}{c}{ Rit } & t-hitung & Probabilitas $(\mathbf{P})$ \\
\hline t -10 & 0,00816491 & 1,611 & 0,114 \\
t -9 & $-0,00164711$ & $-0,433$ & 0,667 \\
t -8 & 0,00737841 & 1,162 & 0,251 \\
t -7 & $-0,00376857$ & $-0,722$ & 0,474 \\
t -6 & 0,00544676 & 1,579 & 0,121 \\
t -5 & 0,00358850 & 0,867 & 0,391 \\
t -4 & $-0,00540880$ & $-1,312$ & 0,196 \\
t -3 & 0,00265091 & 0,458 & 0,649 \\
t -2 & 0,00319052 & 0,761 & 0,451 \\
t - & $-0,00098860$ & $-0,266$ & 0,792 \\
t 0 & 0,00521342 & 1,725 & $0,092 * *$ \\
t 1 & $-0,00374311$ & $-1,311$ & 0,196
\end{tabular}




\begin{tabular}{cccc} 
t 2 & $-0,00068713$ & $-0,240$ & 0,811 \\
t 3 & 0,00222476 & 0,616 & 0,541 \\
t 4 & $-0,00143946$ & $-0,577$ & 0,567 \\
t 5 & 0,00719733 & 2,066 & $0,045^{*}$ \\
t 6 & $-0,00086602$ & $-0,257$ & 0,798 \\
t 7 & 0,00462017 & 1,219 & 0,229 \\
t 8 & $-0,00264283$ & $-0,857$ & 0,396 \\
t 9 & 0,00098798 & 0,359 & 0,721 \\
t 10 & 0,00000000 & 0,000 & 0,000 \\
\hline Keterangan: * & $=$ signifikan pada $\alpha$ sebesar $5 \%$ \\
& $* *=$ signifikan pada $\alpha$ sebesar $10 \%$ & \\
\hline
\end{tabular}

Sumber: data sekunder yang diolah, 2016

Tabel diatas menunjukkan hasil analisis data menunjukkan bahwa selama 21 hari periode pengamatan terdapatreturn saham yang signifikan pada seputaran waktu pengumuman merger dan akuisisi perusahaan. Hasil pengujian data mengindikasikan bahwa pada periode sebelum pengumuman merger dan akuisisi tidak ada diperoleh return saham signifikan pada periode t-10 sampai t-1.

Pada saat pengumuman dan sesudah pengumuman merger dan akuisisi, return sahamyang signifikan hanya terjadi 2 hari yaitu pada saat t0 sampai t5. Atas dasar hasil tersebut, maka Hipotesis I pada penelitian ini yaitu bahwa terdapat reaksi pasar yang diindikasikan dengan return saham pada seputaran waktu pengumuman merger dan akuisisi perusahaan didukung oleh data penelitian. Tetapi, hasil analisis data return saham menunjukkan reaksi pasar sangat kecil terhadap pengumuman merger dan akuisi. Hal ini berarti bahwa pasar atau investor hanya menganggap pengumuman ini sebagai berita yang biasa saja.

Tabel.6. Hasil Uji-t Pada Rata-Rata Rmt Selama Event Window

\begin{tabular}{cccc}
\hline Periode & \multicolumn{1}{l}{ Rmt } & t-hitung & Probabilitas (P) \\
\hline t -10 & 0,00000000 & 0,000 & 0,000 \\
t -9 & 0,00382387 & 2,239 & $0,030^{*}$ \\
t -8 & 0,00012922 & 0,064 & 0,949 \\
t - & 0,00163526 & 0,930 & 0,357 \\
t -6 & $-0,00244528$ & $-1,771$ & $0,083^{* *}$ \\
t -5 & 0,00403302 & 2,208 & $0,032^{*}$ \\
t -4 & $-0,00060672$ & $-0,329$ & 0,744 \\
t -3 & $-0,00054622$ & $-0,309$ & 0,759 \\
t -2 & $-0,00009004$ & $-0,053$ & 0,958 \\
t - & $-0,00088324$ & $-0,541$ & 0,591 \\
t 0 & 0,00141480 & 0,810 & 0,422 \\
t 1 & 0,00077791 & 0,433 & 0,667 \\
t 2 & $-0,00161430$ & $-0,933$ & 0,356 \\
t 3 & 0,00009235 & 0,061 & 0,952
\end{tabular}




\begin{tabular}{cccc} 
t 4 & 0,00180643 & 0,872 & 0,388 \\
t 5 & 0,00291280 & 2,506 & $0,016^{*}$ \\
t 6 & 0,00146370 & 0,912 & 0,367 \\
t $~$ & 0,00396167 & 2,061 & $0,045^{*}$ \\
t 8 & $-0,00102948$ & $-0,640$ & 0,525 \\
t 9 & $-0,00182533$ & $-1,117$ & 0,270 \\
t 10 & 0,00064813 & 0,511 & 0,612 \\
\hline
\end{tabular}

Keterangan: $*$ signifikan pada $\alpha$ sebesar $5 \%$

$$
* *=\text { signifikan pada } \alpha \text { sebesar } 10 \%
$$

Sumber: data sekunder yang diolah, 2016

Hasil pengujian return ekspektasi menggunakan One sample t-test menunjukkan bahwa pasar bereaksi terhadap pengumuman merger dan akuisisi. Tabel diatas menunjukkan adanya return ekspektasi positif yang signifikan yaitu pada t-9, t-6, t-5, t5 dan t7. Hal ini menunjukkan bahwa pasar atu investor menilai bahwa keputusan merger dan akuisisi yang dilakukan perusahaan merupakan keputusan yang tepat. Investor optimis dengan dilakukannya merger dan akuisisi, kinerja perusahaan akan semakin meningkat.

Tabel. 7. Hasil Uji-t Pada AAR Selama Event Window

\begin{tabular}{llll}
\hline Periode & AAR & t-hitung & Probabilitas (P) \\
\hline t -10 & 0,00000000 & 0,000 & 0,000 \\
t -9 & 0,00434115 & 0,911 & 0,367 \\
t -8 & $-0,00177626$ & $-0,507$ & 0,615 \\
t -7 & 0,00574330 & 0,952 & 0,346 \\
t -6 & $-0,00132320$ & $-0,274$ & 0,785 \\
t -5 & 0,00141376 & 0,437 & 0,664 \\
t -4 & 0,00419524 & 1,045 & 0,302 \\
t -3 & $-0,00486257$ & $-1,501$ & 0,140 \\
t -2 & 0,00274089 & 0,464 & 0,645 \\
t -1 & 0,00407374 & 1,096 & 0,279 \\
t 0 & $-0,00238193$ & $-0,596$ & 0,554 \\
t 1 & 0,00432224 & 1,505 & 0,139 \\
t 2 & $-0,00212887$ & $-0,802$ & 0,427 \\
t 3 & $-0,00077957$ & $-0,274$ & 0,785 \\
t 4 & 0,00041839 & 0,125 & 0,901 \\
t 5 & $-0,00435222$ & $-1,798$ & $0,079 * *$ \\
t 6 & 0,00573352 & 1,830 & $0,074 * *$ \\
t 7 & $-0,00482765$ & $-1,805$ & $0,078 * *$ \\
t 8 & 0,00564961 & 1,284 & 0,206 \\
t 9 & $-0,00081752$ & $-0,286$ & 0,776 \\
t 10 & 0,00033987 & 0,139 & 0,890 \\
\hline Keterangan: * & $=$ signifikan pada $\alpha$ sebesar 5\% & \\
& $* *=$ signifikan pada $\alpha$ sebesar $10 \%$ & \\
\hline
\end{tabular}

Sumber: data sekunder yang diolah, 2016 
Tabel diatas menunjukkan hasil analisis data yang mengindikasikan bahwa selama 21 hari periode pengamatan terdapat abnormal return yang signifikan pada seputaran waktu pengumuman merger dan akuisisi perusahaan. Hasil pengujian data mengindikasikan bahwa pada periode sebelum pengumuman merger dan akuisisi tidak ada diperoleh abnormal return signifikan pada periode t-10 sampai t-1.

Sementara itu, pada periode setelah pengumuman merger dan akuisisi terjadi beberapa hari abnormal return yaitu pada saat t5 sampai t7. Atas dasar hasil tersebut, maka Hipotesis I pada penelitian ini yaitu bahwa terdapat reaksi pasar yang diindikasikan dengan abnormal return pada seputaran waktu pengumuman merger dan akuisisi perusahaan didukung oleh data penelitian.

Namun, reaksi yang ditunjukkan pasar sangat kecil. Tetapi, hasil ini mengindikasikan bahwa pasar menilai keputusan merger dan akuisisi yang dilakukan perusahaan merupakan keputusan yang tepat. Adanya optimisme investor mengenai kinerja proses merger dan akuisisi perusahaan menyebabkan naiknya permintaan akan saham-saham perusahaan yang melakukan merger dan akuisisi, sehingga menyebabkan adanya abnormal return positif pada periode ini.

\section{Hasil Pengujian Hipotesis II}

Pengujian pada Hipotesis II ini bertujuan untuk membuktikan apakah terdapat perbedaan yang signifikan atas harga saham, return saham, return ekspektasi dan abnormal return saham di antara periode sebelum dan sesudah pengumuman merger dan akuisisi perusahaan. Uji dilakukan dengan teknik analisis Paired Sample T-test dengan $\alpha=5 \%$. Hasil pengujiannya adalah sebagai berikut ini.

Tabel. 8. Hasil Uji Beda Harga Saham Periode Sebelum dan Sesudah Pengumuman Merger dan Akuisisi Paired Samples Test

\begin{tabular}{|c|c|c|c|c|c|c|c|c|c|}
\hline & \multicolumn{5}{|c|}{ Paired Differences } & \multirow[t]{3}{*}{$\mathrm{t}$} & \multirow[t]{3}{*}{$\mathrm{df}$} & \multirow{3}{*}{$\begin{array}{l}\text { Sig. (2- } \\
\text { tailed) }\end{array}$} \\
\hline & & \multirow[t]{2}{*}{ Mean } & \multirow[t]{2}{*}{$\begin{array}{c}\text { Std. } \\
\text { Deviation }\end{array}$} & \multirow[t]{2}{*}{$\begin{array}{c}\text { Std. Error } \\
\text { Mean }\end{array}$} & \multicolumn{2}{|c|}{$\begin{array}{l}95 \% \text { Confidence } \\
\text { Interval of the } \\
\text { Difference }\end{array}$} & & & \\
\hline & & & & & Lower & Upper & & & \\
\hline Pair 1 & $\begin{array}{l}\text { Harga Saham } \\
\text { Sebelum M \& A - } \\
\text { Harga Saham } \\
\text { Sesudah } M \text { \& A }\end{array}$ & 13,19363 & 144,84484 & 21,35621 & $-29,81998$ & 56,20724 & ,618 & 45 & ,540 \\
\hline
\end{tabular}

Sumber: data sekunder yang diolah, 2016

Tabel diatas diperoleh hasil nilai t-hitung sebesar 0,618 dan tarafsignifikansi observasinya sebesar 0,540 . Berdasarkan aturan pengambilan keputusan maka hipotesis kedua dapat disimpulkan bahwa tidak terdapat perbedaan rata-rata harga sahamsebelum dan sesudah pengumuman merger dan akuisisi karena dari pengujian Paired Sample T-test diatas menghasilkan nilai t-hitung $=0,618<\mathrm{t}$ tabel $=2.0141$ serta taraf signifikansi observasinya $=0,540>\alpha=(0,05)$. 
Tabel. 9. Hasil Uji Beda Rit Periode Sebelum dan Sesudah Pengumuman Merger dan Akuisisi

Paired Samples Test

\begin{tabular}{|c|c|c|c|c|c|c|c|c|c|}
\hline & \multicolumn{5}{|c|}{ Paired Differences } & \multirow[t]{3}{*}{$\mathrm{t}$} & \multirow[t]{3}{*}{$\mathrm{df}$} & \multirow{3}{*}{$\begin{array}{l}\text { Sig. }(2- \\
\text { tailed) }\end{array}$} \\
\hline & & \multirow[t]{2}{*}{ Mean } & \multirow[t]{2}{*}{$\begin{array}{c}\text { Std. } \\
\text { Deviation }\end{array}$} & \multirow[t]{2}{*}{$\begin{array}{l}\text { Std. Error } \\
\text { Mean }\end{array}$} & \multicolumn{2}{|c|}{$\begin{array}{l}\text { 95\% Confidence Interval of } \\
\text { the Difference }\end{array}$} & & & \\
\hline & & & & & Lower & Upper & & & \\
\hline Pair 1 & $\begin{array}{l}\text { Rit Sebelum M \& } \\
\text { A - Rit Sesudah } \\
M \text { \& A }\end{array}$ & 001015022, & ,010135769 & ,001494438 & -,001994930 & ,004024974 & 679 & 45 & , 500 \\
\hline
\end{tabular}

Sumber: data sekunder yang diolah, 2016

Dari hasil uji Paired Sample t-test yang tertera pada tabel di atas, dapat diketahui bahwa untuk periode sebelum-sesudah pengumuman, asymptotic sig. menunjukkan nilai 0,500 , atau berada di atas signifikansi $5 \%$. Dengan demikian maka hipotesis $\mathrm{H} 2$ ditolak dan dapat diartikan bahwa tidak terdapat perbedaan yang signifikan abnormal return pada periode sebelum dan sesudah pengumuman merger dan akuisisi.

Tabel. 10. Hasil Uji Beda Rmt Periode Sebelum dan Sesudah Pengumuman Merger dan Akuisisi

Paired Samples Test

\begin{tabular}{|c|c|c|c|c|c|c|c|c|c|}
\hline & \multicolumn{5}{|c|}{ Paired Differences } & \multirow[t]{3}{*}{$t$} & \multirow[t]{3}{*}{$\mathrm{df}$} & \multirow{3}{*}{$\begin{array}{l}\text { Sig. }(2- \\
\text { tailed) }\end{array}$} \\
\hline & & \multirow[t]{2}{*}{ Mean } & \multirow[t]{2}{*}{$\begin{array}{l}\text { Std. } \\
\text { Deviation }\end{array}$} & \multirow[t]{2}{*}{$\begin{array}{l}\text { Std. Error } \\
\text { Mean }\end{array}$} & \multicolumn{2}{|c|}{$\begin{array}{c}95 \% \text { Confidence Interval of } \\
\text { the Difference }\end{array}$} & & & \\
\hline & & & & & Lower & Upper & & & \\
\hline Pair 1 & $\begin{array}{l}\text { Rmt Sebelum M } \\
\& A-R m t \\
\text { Sesudah M \& }\end{array}$ & -,000158239 & ,004166838 & ,000614367, & -,001395637 & 001079159 & -258 & 45 & 798 \\
\hline
\end{tabular}

Sumber: data sekunder yang diolah, 2016

Berdasarkan tabel diatas, pengujian dilakukan dengan Paired Sample t-test dengan $\alpha=5 \%$ memberikan nilai t-hitung $-0,258>0,05$. Hal ini menunjukkan bahwa tidak terdapat perbedaan return saham sebelum dan sesudah pengumuman merger dan akuisisi.

Tael. 11. Hasil Uji Beda AAR Periode Sebelum dan Sesudah Pengumuman Merger dan Akuisisi Paired Samples Test

\begin{tabular}{|c|c|c|c|c|c|c|c|c|c|}
\hline & & \multicolumn{5}{|c|}{ Paired Differences } & \multirow[t]{3}{*}{$\mathrm{T}$} & \multirow[t]{3}{*}{$\mathrm{df}$} & \multirow{3}{*}{$\begin{array}{l}\text { Sig. (2- } \\
\text { tailed) }\end{array}$} \\
\hline & & \multirow[t]{2}{*}{ Mean } & \multirow[t]{2}{*}{$\begin{array}{c}\text { Std. } \\
\text { Deviation }\end{array}$} & \multirow[t]{2}{*}{$\begin{array}{l}\text { Std. Error } \\
\text { Mean }\end{array}$} & \multicolumn{2}{|c|}{$\begin{array}{l}95 \% \text { Confidence Interval of } \\
\text { the Difference }\end{array}$} & & & \\
\hline & & & & & Lower & Upper & & & \\
\hline Pair 1 & $\begin{array}{l}\text { Abnormal Return } 10 \\
\text { hari sebelum } \\
\text { Abnormal Return } 10 \\
\text { hari sesudah }\end{array}$ & ,001247696 & ,009235577 & ,001361712 &,- 001494932 & ,003990324 & ,916 & 45 & ,364 \\
\hline
\end{tabular}

Sumber: data sekunder yang diolah, 2016 
Tabel di atas menunjukkan bahwa nilai t-hitung sebesar 0,916 dengan probabilitas (p) sebesar 0,364. Sesuai dengan kriteria pengambilan simpulan dalam hipotesis II penelitian ini, maka penelitian ini tidak dapat membuktikan secara empiris bahwa terdapat perbedaan abnormal return pada periode sebelum dan setelah pengumuman merger dan akuisisi perusahaan oleh karena nilai probabilitas $(p)>\alpha=0,05$ yaitu sebesar 0,916 . Atas dasar hasil penelitian ini, maka dapat disimpulkan bahwa hipotesis II dalam penelitian ini tidak didukung oleh data penelitian.

Berdasarkan hasil analisis pada keseluruhan sampel selama periode pengamatan terdapat return saham, return ekspektasi dan abnormal return positif yang signifikan pada tingkat 5\% dalam beberapa hari periode peristiwa. Secara umum hasil penelitian ini menerima hipotesis yang diajukan, yang berarti terdapatreturn saham, return ekspektasi dan abnormal return yang signifikan pada seputaran waktu pengumuman merger dan akuisisi perusahaan yang membuktikan bahwa pasar bereaksi terhadap pengumuman merger dan akuisisi.

Terjadinya penurunan harga saham, return saham, return ekspektasi dan abnormal return dalam beberapa hari periode penelitian mengindikasikan bahwa pengumuman akuisisi itu sendiri bukan merupakan sebuah kabar yang mengejutkan. Informasi tersebut telah diketahui publik sebelumnya atau adanya kebocoran informasi terlebih dahulu sebelum dilakukan pengumuman. Kebocoran informasi terlebih dahulu sebelum dilakukan pengumuman adalah hal wajar yang disebabkan oleh proses pelaksanaan akuisisi yang membutuhkan waktu agak lama.

Berdasarkan hasil analisis menggunakan uji Paired Sample t-test diperoleh hasil bahwa tidak terdapat perbedaan harga saham, return saham, return ekspektasi dan abnormal return sebelum dan sesudah pengumuman merger dan akuisisi. Hal ini disebabkan karena informasi sudah terdistorsi sebelum pengumuman dilakukan sehingga muatan informasi yang ditimbulkan tidak memiliki makna. Pasar tidak bereaksi secara signifikan jadi tidak terdapat perbedaan return saham yang diperoleh oleh pemegang saham. 


\section{KESIMPULAN DAN SARAN}

\section{Kesimpulan}

1. Secara keseluruhan rata-rata return saham, return ekspektasi dan abnormal return bertanda positif lebih besar dibandingkan dengan yang bertanda negatif. Hasil tersebut mengindikasikan bahwa pemegang saham perusahaan akusitor memperoleh tambahan kemakmuran dari aktivitas merger dan akuisisi, atau rata-rata return saham, return ekspektasi dan abnormal return positif diperoleh pemegang saham perusahaan akuisitor diseputar tanggal pengumuman merger dan akuisisi.

2. Penelitian ini mampu membuktikan bahwa pengumuman merger dan akuisisi menghasilkan return saham, return ekspektasi dan abnormal return yang signifikan pada periode di sekitar tanggal pengumuman. Hal ini dapat dilihat dari dihasilkannya return saham yang signifikan pada beberapa hari periode penelitian, namun return yang dihasilkan sangat kecil karena jumlah periode yanag signifikan hanya 9 hari.

3. Hasil perhitungan uji beda rata-rata menunjukkan bahwa secara statistik tidak terdapat perbedaan yang signifikan antara rata-rata harga saham, return saham, return ekspektasi dan abnormal return sebelum dan sesudah pengumuman merger dan akuisisi. Hal ini ditunjukkan dengan nilai t-hitung < t-tabel, dan taraf signifikan observasinya $>5 \%$. Hal inimengindikasikan respon investor yang sama pada periode sebelum dan setelah pengumuman merger dan akuisisi oleh karena belum dapat terukurnya kinerja perusahaan dalam jangkapendek.

\section{Saran}

1. Memperpanjang periode penelitian dengan harapan dapat diperoleh jumlah sampel dan observasi yang lebih banyaksehingga dapat diperoleh hasil penelitian yang lebih baiksecara statistik.

2. Memisahkan periode pengamatan yaitu long event windowdan short event window agar hasil yang didapat lebih akurat.

3. Menggunakan metode atau pendekatan yang lain dalammengukur abnormal return seperti pendekatan pasar atau pasar yang disesuaikan agar dapat diperoleh hasil penelitianyang lebih baik. 


\section{DAFTAR PUSTAKA}

Edward, M.Y. 2012. Analisis Reaksi Pasar Atas Pengumuman Merger dan Akuisisi.Jurnal Dinamika Ekonomi dan Bisnis.Vol.9, No.1.

Floyd A. Beams dan Amir Abadi Jusuf, 1999. Akuntansi Keuangan Lanjutan Di Indonesia, Buku Satu, Salemba Empat.

Karyawati, Golrida. 2009. Akuntansi Keuangan Lanjutan (Advanced Accounting). Jakarta: Erlangga.

Meilany, Kania Intan. 2008. Analisis Pengaruh Merger dan Akuisisi Terhadap Return Saham, Volume Perdagangan Saham, Risiko Sistematis, dan Kinerja Keuangan Pada Perusahaan Go Public di BEI. Skripsi. Jakarta: Universitas Islam Negeri Syarif Hidayatullah.

Mohamad Heykal, Monica Hennisia Wijayanti. 2015. Analisis Hubungan Antara Merger dan Akuisisi Terhadap Kinerja Keuangan dan Return Saham Pada Perbankan yang Terdaftar Di BEI. Jurnal Akuntansi, Keuangan dan Perbankan. Vol.1, No.3.

Novaliza, Putri dan Atik Djajanti. 2013. Analisis Pengaruh Merger dan Akuisisi Terhadap Kinerja Perusahaan Publik di Indonesia (Periode 2004-2011). Jurnal Akuntansi dan Bisnis.Vol.1, No.1.

R. Drebin, Allan. 2006. Advanced Accounting. Jakarta: Erlangga.

Rahmawati, Indah. 2007. Pengaruh Merger dan Akuisisi Terhadap Kinerja Keuangan Perusahaan Manufaktur Go Public di Indonesia.Skripsi. Surakarta: Universitas Sebelas Maret.

Rumondang, Astri. 2010. Analisis Dampak Pengumuman Merger dan Akuisisi Terhadap Abnormal Return Saham Perusahaan.Skripsi. Surakarta: Universitas Sebelas Maret.

Sianturi, Heriston. 2010. Analisis Pengaruh Perlakuan AkuntansiPenggabungan Usaha Terhadap Harga Saham. Jurnal Ilmiah Satya Negara Indonesia.Vol.3, No.1. 
Slamat Harijono Aritonang, Atim Djazuli dan H.M. Harry Susanto.2009. Analisis Return, Abnormal Return, Aktivitas Volume Perdagangan Atas Pengumuman Merger dan Akuisisi.Wacana.Vol.12, No.4.

Widyastuti, Ira. 2010. Analisis Perbandingan Return dan Risiko Pemegang Saham Sebelum dan Sesudah Merger dan Akuisisi.Skripsi. Surakarta: Universitas Sebelas Maret.

www.idx.co.id

www.kppu.go.id

finance.yahoo.com 